\title{
Pesantren and the preservation of traditional religious authority in the digital age
}

\section{Pesantren dan preservasi otoritas keagamaan tradisional di era digital}

\author{
Dodik Harnadi ${ }^{1 *}$, Hotman Siahaan ${ }^{2}$, Masdar Hilmy ${ }^{3}$ \\ ${ }^{1}$ Doctoral Program of Social Science, Faculty of Social and Political Science, \\ Universitas Airlangga \\ ${ }^{2}$ Department of Sociology, Faculty of Social and Political Sciences, Universitas Airlangga \\ ${ }^{3}$ Islamic Studies Doctoral Program of Postgraduate Studies, \\ Sunan Ampel State Islamic University \\ Address: ${ }^{1,2}$ Jalan Dharmawangsa Dalam Selatan, Surabaya, East Java 60286 \\ ${ }^{3}$ Jalan Ahmad Yani No 117, Surabaya, East Java 602111 \\ Email: dodik.harnadi-2017@fisip.unair.ac.id
}

Article History: Received 3 May 2020; Accepted 12 June 2021; Published Online 22 June 2021

\begin{abstract}
Kiai is the Javanese term of ulama in the traditional Muslim community. It generally refers to a person who has a deep understanding of Islam and leads the institution of traditional Islamic education called pondok pesantren or Islamic boarding school. Indeed, the strength of a Kiai is based on his leadership at the pesantren that has functioned as a space for cultural-social reproduction. While the attention of many researchers focused on the shifting of Islamic authority in the digital age, not much of them paid special attention to the survival of Kiai's authority. This study aims to examine the role of pesantren in preserving the authority of the Kiai in the digital age. This study employed qualitative method and utilized the cultural reproduction theory of Pierre Bourdieu. This study found that Kiai's authority continues to survive because pesantren functioned as a space for transmitting cultural values, including the recognition of Kiai's high position. As a social and cultural reproduction space, pesantren becomes a field that forms habitus through the transmission of its cultural values which is naturally formed in the daily practices of the santri.
\end{abstract}

Keywords: cultural reproduction; digital; Kiai; religious authority

\begin{abstract}
Abstrak
Kiai adalah istilah Jawa dari kata ulama dalam komunitas Muslim tradisional. Kiai umumnya mengacu kepada seseorang yang memiliki pemahaman mendalam terhadap materi-materi keislaman serta memimpin institusi pendidikan Islam yaitu pondok pesantren atau sekolah asrama Islam. Pada dasarnya, kekuatan Kiai didasarkan atas kepemimpinannya di pesantren yang telah berfungsi sebagai ruang reproduksi budaya-sosial. Sementara perhatian banyak peneliti fokus pada pergeseran otoritas Islam di era digital, tidak banyak dari mereka yang memberikan perhatian terhadap keberlangsungan otoritas Kiai. Studi ini bertujuan untuk mengkaji peran pesantren dalam mempertahankan otoritas kiai di era digital. Studi ini menggunakan metode kualitatif dengan memanfaatkan teori reproduksi budaya Pierre Bourdieu. Kajian ini menemukan bahwa otoritas Kiai terus bertahan karena pesantren berfungsi sebagai ruang transmisi nilai-nilai kultural termasuk pengakuan terhadap posisi tinggi Kiai. Sebagai ruang reproduksi sosial dan budaya, pesantren menjadi medan yang membentuk habitus yang terbentuk melalui transmisi nilai-nilai kebudayaan pesantren yang secara alami dibentuk di dalam praktik sehari-hari kaum santri.
\end{abstract}

Kata kunci: reproduksi budaya; digital; Kiai; otoritas agama

\section{Introduction}

Religious topics related to the digitized society have widespread around the world and have become one of the cutting-edge debates in the field of religious study. Many researchers gave attention to the relation between religion and digital matters (Bunt 2003; Chaves 1994; Giorgi 2019; Hjarvard 2016; Rahman 2017; Turner 2007). Some of them examined the change of religious authority in an increasingly mediated 
world as well as concerned about the rise of new religious authority in the mass media space (Chaves 1994; Giorgi 2019; Hjarvard 2016; Rahman 2017; Turner 2007). Preserving the classical religious authority has become one of the main topics in digitized society along with the shifting happened that is marked by the emerging of the new religious authority. According to Oxford Learners Dictionary (OUP 2021), the word preservation literally refers to "the act of keeping something in its original state or in good condition" or "the act of making sure that somethings is kept". The word was conceptually used in an interdisciplinary study to suggest the act of protecting something matters like cultural heritage (Hayden \& Wong, 1997; Zhou et al.2012) and identity (Vittoria 1998; Zhang 2010).

In this study, the concept of preservation is used to explain the role of pesantren in keeping the status of Kiai as an old religious authority, especially with the emergence of new religious authority in digital space. In the situation, Dale Eickelman and James Piscatori (2004) referred to as the fracturing of Islamic authority, Kiai 's role is preserved by the function of pesantren as a social and cultural reproduction space. Compared to Christian, the discourse of religious authority in Islam in the digital age and the shifts that occur might be more interesting. It cannot be separated from the structure of Islamic authority that is poorly institutionalized and less hierarchical than, to take an example, Christian structure (Peter 2006).

Therefore, the figures with authoritative power in Islam dispersed around many individuals. Religious authority was attached to one with the ability to interpret the authoritative text of Islam. The authoritative texts of Islam are the Al-Quran and the Hadith. Because many people have the authoritative ability to interpret both, so who will be the figure to be followed depending on the beliefs and perceptions of each person to the figure (Turner 2007). Ulama is one of the authoritative figures in Islam who is placed as a central figure due to his mastery of Islamic insights. The ability to interpret the authoritative texts of Islam, namely Al-Quran and Hadith, is the main capital that makes the ulama occupy the religious authority. Therefore, the ability makes the ulama an influential figure in the socio-cultural spectrum of Islamic society. Ulama gets special privileges due to their deep knowledge of Islam (Zulkifli 2013). In Indonesia, there are various terms pinned to the ulama. Kiai was another name for the ulama which is used by most Indonesian Muslims, especially those affiliated with the traditional Muslim of Nahdlatul Ulama (NU). Different from other categories such as Ustaz (Islamic teacher), the influence of the Kiai was formed by two aspects at once. First, it is wisdom in the field of religion. Second, it is Kiai's leadership in a religious education institution called pondok pesantren or Islamic boarding school (Rahman 2017).

For this purpose of study, the categorization of Kiai such as Kiai Pesantren, Kiai Tareqa (Kiai who practices the Sufi order, that is commonly known as tareqa), and Kiai involves in politics (Turmudi 2006) is avoided. Those who are called Kiai are the leaders of pondok pesantren or at least family members of the leader. Therefore, it includes either Kiai Tareqa or Kiai involved in politics who are related to the leadership of pondok pesantren. While the attention of many researchers focused on the shifting of the Islamic authority in the digital age (Robinson 1993; Bano 2018), not much of them paid special attention to the survival of Kiai's authority. This shift in authority does not only occur in the Islamic environment. Some western scientists have also long been concerned with the phenomenon of shifting of religious authority in Christianity, both caused by secularization (Chaves 1994) and the wave of technological change (Giorgi 2019). In contrast to the authority of the ulama in general, that of the Kiai in the digital era seemed to remain upright. The unique authority of the Kiai as one of the distinctive ulama entities makes it happen. To sum up, there are two main questions that this study wants to examine. First, how the role of pesantren as a reproduction space for cultural values functions to maintain the authority of the Kiai? Second, what is the strength of pesantren that enables it to succeed in maintaining the authority of Kiai amid the emergence of other religious authority produced by the media?

\section{Research Method}

To answer the two questions, this study used library research by exploring the theoretical and conceptual debates on religious authority, pesantren and/or Kiai. At first, the study started from reviewing theoretical debates on Kiai as a religious authority as well as pesantren and then presenting a theoretical sketch 
of Pierre Bourdieu's cultural reproduction theory. The library-based data was analyzed by a qualitative method that emphasizes the subjective and thick description to understand the phenomenon. Standing on Bourdieu's theory, in the final stage, some conceptual matters were proposed to enrich the discourses of Kiai in terms of his position as a religious authority in the digital era nowadays.

In contrast to other religions, religious authority in Islam is less institutionalized (Peter 2006). Therefore, for some scientists, this situation is the most remarkable aspect of the study of religious authority in Islam. In Christianity, for instance, the institutionalizing process of religious authority is evident in Christian institutions both at national and transnational levels. Due to the institution, the religious authority in Christianity is relatively clear and unchanged. On the other hand, the religious authority of Islam spread to various figures, sometimes contest each other (Burhani, 2018). Generally, it relates to their ability to interpret the authoritative texts of Islam.

\section{Results and Discussion}

\section{Kiai as a religious authority in Islam}

Kiai is another term of ulama in Javanese culture. He is a Javanese variant of ulama, although Kiai has a more specific dimension. If the ulama broadly refers to those who have deep expertise in the field of religion, then Kiai specifically has a special feature that must be pinned, which is the leadership of the educational institution called pondok pesantren (Rahman 2017). Uniquely, the religious authority owned by Kiai does not only comes from its mastery of Islamic teachings as well as its ownership of boarding schools but also the belief of the follower of Kiai in its power. Kiai's authority is similar to the charismatic authority in Max Weber's theory. According to Weber, the charismatic authority adheres to those whose authority does not originate from certain institutions or knowledge, but from the belief of the followers to their strengths, both physically and mentally (Buisman et al. 2015). This authority for Kiai is manifested in various forms and ways. For traditional society, there was a generally strong recognition that Kiai has a supernatural being that common people do not have. They generally call it karomah, an Arabic-speaking term for beyond human power, despite its terminological meaning goes beyond mere physical circumstances.

The story of Kiai's miracles as karomah can be found easily in the history of colonialism in Indonesia. Such a miracle can be found in the story of one Kiai in Situbondo, East Java, namely Kiai As'ad Syamsul Arifin, who successfully conquered colonial cannon by empty hand. Even for Muslim villagers, the story strengthens the charisma of the Kiai. Barakah (blessing) can be regarded as one of the important power that is more mental than physical. With barakah, the charismatic authority of Kiai is gaining legitimacy. As one who has a gift from God in giving blessings, Kiai is regarded a holy man by villagers (Turmudi 2006). As a religious authority, Kiai was placed as the elite. The notion of the elites refers to a little group of people, who is due to their advantage, enjoy the influence and privilege of their followers (Mouline 2011). As an elite, Kiai occupies the top hierarchy of the social pyramid. Kiai is respected and obeyed. In certain conditions, he is a justifier of any form of social change.

In traditional society, little change is not always easy. For some reasons and conditions, the social invention is considered taboo and the inventor is socially exiled. On the contrary, it will not happen to Kiai and his descendant namely Gus or Lora. Kiai can either maintains or breaks the culture off by forming a new one without meaningfully getting resistance from society. This circumstance confirms Kiai's role as an effective 'cultural broker' (Geertz 1960) by which the change of any social dynamic is the more likely to happen. Kiai's position as a patron enables him to transform certain forms of culture into a new one that is easily accepted by people. The patronage of Kiai is formed in his relation with santri as a client (Fox \& Dirjasanjoto 1989). Santri is a student learning religious matters in pondok pesantren under Kiai's direction. For santri, obedience to Kiai is a key to success in obtaining the blessing of living. Therefore, whatever is said by Kiai is an obligation for santri. 
The word santri here is different from the same word used by Clifford Geertz in his Religion of Java. The word santri used by Geertz (1960) referred to the identity of certain Muslim variants with the purer religious category. This santri highly avoids the infiltration of local cultures into Islamic rituals. For the latter, Geertz used the word Abangan. From this point of view, the word santri used by Geertz is more suitable for the variant of Muslim modernists such as Muhammadiyah than those of Nahdlatul Ulama'. Meanwhile, santri as well as Kiai, in the sense of pondok pesantren is the representation of traditional Muslims where their religious views are more tolerant and accommodating into the culture. The ritual of Slametan as Geertz attributed to Abangan is accepted and conserved by traditional Muslims. Although the word santri narrowly refers to those who have been pupils of pondok pesantren (Pribadi 2014), it is empirically extensive. Santri is not merely those who have learned and stayed for a certain time in pondok pesantren but also those who pledged themselves as a follower of Kiai.

This proposition is more visible in looking at the relation between tarekat Kiai or murshid, and santri who is commonly called Ikhwan, the Arabic plural form of akh which means brother. Tarekat as a mystical brotherhood had played an important role in Indonesian Muslim society, especially the Madurese (Bruinessen 1995). Likely, the Ikhwan never had been pupils in pesantren, but in the sense of tarekat, their relations with Kiai were sacred. Ikhwan considers themselves as students for murshid and obeys him to obtain salvation. As Ikhwan believes that obedience to murshid is the only way to obtain salvation, they voluntarily subjugate themselves to murshid or Kiai. Therefore, the obedience of Ikhwan to Kiai by comparative is occasionally tighter than those who have ever been pupils in pesantren. For this reason, tarekat Kiai often becomes the center of gravity in political contestation due to his authority to politically mobilize Ikhwan (Turmudi 2006).

\section{Bordieu and cultural reproduction}

Pierre Bourdieu's socio-cultural reproductive theory essentially occurs in response to the injustice continually reproduced in western capitalist society (Bourdieu 1973). Educational institutions are the most important media in maintaining injustice through the transmission of cultural values that appreciate the existence of high social classes. According to Bourdieu, there is a close connection between education, family, and social class (Milde \& Aurini 2015). Understanding Bourdieu's socio-cultural reproduction ideas require the importance of understanding the main conception of the relationship between structure and agent as a deciding factor in society. Bourdieu was one of the sociologists who were categorized as thinkers with the idea of integrating agencies and structures Ritzer and Stepnisky (2012).

In the field of sociology, the debate about the relationship between structure and agency is always polemic. Anthony Giddens (1986) described two extreme forms of dualism, with which society is formed. The English sociologist called both subjectivism, the tendency to make the subject a decisive factor, and Objectivism, centered on object determination. This view of dualism, according to Giddens, is untenable. Alternatively, it offers structural theories based on the principle of duality, which is the unification of agents and structures where each other effects and cannot be separated (Giddens 1986 in Craib 1992).

Unlike Giddens, when rejecting dualism and attempting to reconcile the subjects, Bourdieu formulated a theory that emphasized the dialectics of both. In the social context, the existence of the subject is an important aspect in order to build the social world and interpret the meaning therein. Nevertheless, it is not entirely free because it is limited by the social structure (Ritzer \& Stepnisky 2012). To understand Bourdieu's intention, discuss his idea of habitus and the field can help. Habitus alone refers to the subjectivity of an agent that affects how to socialize and form through a long-lasting interrelated experience. It is a mental and cognitive structure that determines the way one relates to the social world (Ritzer \& Stepnisky 2012).

Each person's habitus is influenced by their respective historical environment. The field is a world that is outside the mental structure of habitus, but affects how habitus is formed. Nevertheless, the 
field is closely related to habitus. Bourdieu's idea of the field refers to the belief that certain social spaces affect certain principles that do not exist in other areas (Albright et al. 2018). That is, the field is a football field, while habitus is the way the players relate to football and all the attributes attached to the field. Everyone is influenced by the ownership of a number of capital in social areas. One of its capital is cultural capitals, a code and cultural practice that can be transmitted from generation to generation through various channels, including family and educational institutions. For this reason, there is a close connection between school institutions, cultural capital, and everyone's habits. Cultural values that characterize one's habits are reproduced through an educational institution. This is where the educational institution as a socio-cultural reproductive chamber, according to Bourdieu, plays a role in recycling injustice (Tzanakis 2011).

Bourdieu's ideas rested on his criticism of the educational space that helped preserve the culture of the elite status (Milde \& Aurini 2015). Rather than establishing a critical stance, the school's educational environment increasingly confirms the elite position of certain groups. Cultural reproduction theory is useful for explaining how cultural features are transmitted from one generation to another. In particular, Bourdieu emphasized the importance of this theory to explain the reproduction of the socio-economic position of a person between generations (Jæger \& Breen 2016).

\section{Pesantren as space for cultural reproduction}

Pesantren is a traditional Islamic educational institution. Indeed, some historians noted that this educational institution stood long before other Islamic education developed in Indonesia (Athyal 2015). As an educational institution, Kiai functions as the driver as well as an agent that determines the direction and philosophy of the learning model inside it. As a traditional educational institution, the pesantren's uniqueness lies similarly in the centrality of the Kiai's role. The centrality of Kiai is not only because he is institutionally stood in the highest hierarchy in the management structure of pesantren, but also due to people's belief in the transcendental power of Kiai. As a central figure, as described by Weber, the Kiai's authority lied more in their charisma rather than his structural strength in the pesantren organization. The charisma of the Kiai, for example, is often associated with their role, such as a medium for the santri to get a blessing (barakah) (Turmudi 2006).

It is often said that rather than accumulating knowledge, the task of a santri that is no less important is to get blessings from the Kiai. No matter how much knowledge a santri has, without the blessing from the Kiai, it would be considered valueless (Huda et al. 2016). Consequently, Kiai's blessing leads to the total submission of the santri. This submission does not only survive in the boarding school environment. The submission of the santri goes beyond the spatial and time barriers. When the santri were in society, there was almost nothing different from their submission to the Kiai. This condition makes Kiai occupy the highest hierarchy in the stratification of traditional rural communities (Turmudi 2006). For example, in Madurese society, there is an expression of bhupak-bhebuk-ghuru-rato which places the Kiai at the level of figures who must be respected after parents and before leaders.

The lifeworld, borrowing the theory of Alfred Schutz (in Dreher 2011), in the pesantren formed the conceptions of the santri regarding the chastity of the Kiai. This chastity persisted until they left the pesantren and became real members of the community. For that reason, the pesantren functions as a socio-cultural reproduction space that nurtures the charisma and chastity of Kiai. As a social and cultural reproductive space, it is worthy to place pesantren as an institution that maintains social stratification as Bourdieu said.

The function of the socio-cultural reproduction of the pesantren is suitable if it is associated with two main conceptions of the pesantren among many observers. First, Wahid (2001) conceptually referred to pesantren as a sub-culture, which marks the existence of a sub-group of larger social groups creating a unique cultural structure and is different from the parent culture. Second, another scholar refers to Kiai as a cultural broker (Geertz 1960). As cultural intermediaries, Kiai becomes a trend center for daily behavior which in its development spawns a culture that is accepted and followed by students. 
The position of the Kiai as a cultural broker confirms the function of the pesantren as a socio-cultural reproduction space where the Kiai becomes the main determinant.

If Bourdieu sees the function of socio-cultural reproduction of educational institutions from the point of maintaining social stratification, then the position of pesantren as an educational institution that fortifies the religious authority of the Kiai should also be seen in the midst of shifting religious authority as a result of the internet era of things. Pesantren functions as the guardian of traditional religious authority from the point of view of its functionality as a space for socio-cultural production which is the emphasis of this research. By using Bourdieu's socio-cultural theory of reproduction, this study seeks to explain how the authority of the Kiai is maintained in an era of technological media where traditional religious authority is challenged.

\section{The way Islamic boarding schools fortify the Kiai's authority}

Amid the shift in religious authority in the digital age, Kiai as a religious authority among the traditional Muslim community remains irreplaceable (Wahid 2021). This is due to the pesantren itself, which not only functions as an Islamic educational institution but also a means of reproduction of traditional values of respect for Kiai (Widiyanto 2016). Technological developments, which some are considered as a factor in the shifting of religious authority, have relatively little impact on the dynamics of traditional religious authority. Islamic boarding schools which to some extent distance themselves from technology have been quite successful in maintaining pesantren's fundamental value, even if only temporarily, which is the placement of Kiai as a central figure (Abaza 2002; Suradi \& Surahman 2020).

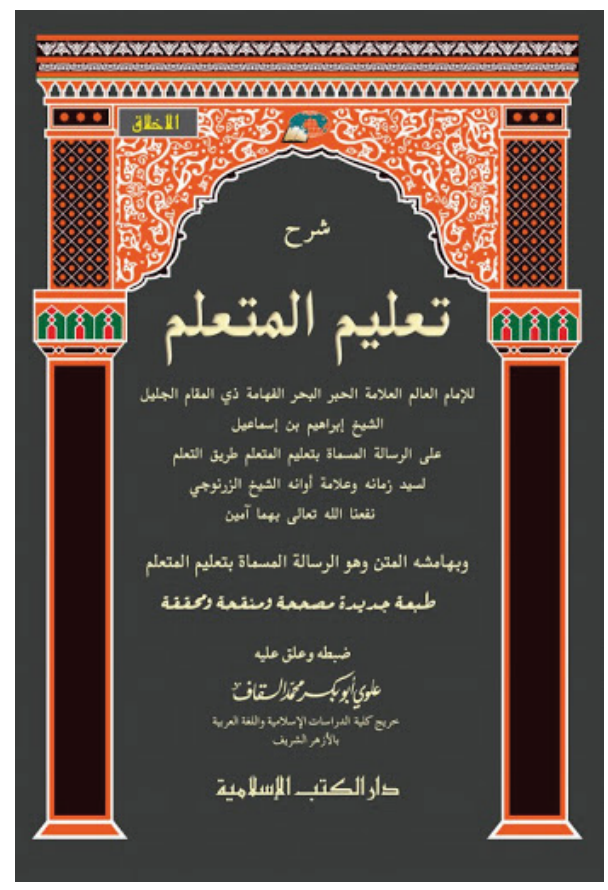

Figure 1.

Book of ta'lim muta'allim

Al-Zarnuji (1986)

What has not changed from the pesantren circles is the assumption that pondok pesantren is still considered a source of religious authority (Widiyanto 2016). Also, as an educational institution, pesantren is an effective space for the reproduction of values and characteristics which emphasize respect for the Kiai. As a space for social and cultural reproduction, it becomes a place that forms the sacred habitus, the value of respect for the Kiai. In pesantren, habitus is formed through the transmission of cultural values that are naturally formed in the daily practices of the santri. Besides, naturally, the pesantren learning structure is carried out by referring to some learning curriculum that emphasizes the importance of 
respecting Kiai. One of them is learning ta'lim muta'allim which means 'learning of learners', a classic book that guides the ideal learning model in pesantren as shown in figure 1.

This book emphasizes the importance of respecting teachers as a prerequisite for gaining useful and blessing knowledge. The word barakah is a divine power that is believed that the main way to get it is by respecting Kiai. Even the concept of barakah, blessing, is the main goal sought by students in studying in Islamic boarding schools. The way to gain it is not limited to study only but also respect for the Kiai. As blessing is not limited at the Islamic boarding school, so the students continue to seek the blessing of Kiai after graduation by maintaining obedience and submission to him. The concept of barakah continues to be reproduced and becomes an important factor in the maintenance of a Kiai's authority. Since barakah is not only oriented solely on Islamic science but also devotion to the Kiai, so it is not found for example in the sense of religious authority mediated by digital platforms. The popularity of Kiai is indeed inferior to the preacher or religious figures who were born and raised through social media. Just looking for scientific insights, students can refer to them. As a figure with religious authority whose blessing is to be gained, no other figures are viewed as comparable to Kiai.

To conclude, there are two ways pesantren as a socio-cultural space preserves the authority of the Kiai. First, the daily world of pesantren which shows the way Kiai should be treated with respect is a field that forms a culture of high respect for the Kiai. Consequently, the everyday world colors the way the santri relate to the social environment. In this process, habitus is formed naturally. Second, the injection of knowledge that takes place at the pesantren is full of values that encourage respect for the Kiai. One of the scientific formulations taught is centered on the obligation to respect the Kiai. Thus, barakah is an important concept in the process of seeking knowledge in pesantren, which can be obtained mainly by respecting the Kiai. It is this blessing that makes it difficult for Kiai to be replaced by the new religious authority of digital media products.

\section{The strength of pesantren in maintaining the Kiai's authority}

The Kiai not only functions as a cultural mediator (cultural broker) but also filters other values that enter the pesantren (Misra \& Chandiramani 2005). This function also functions to maintain the purity of the Kiai's authority from the invasion of other religious authorities. To maintain the purity of cultural values, the pesantren has been relatively remote from the development of technology. On the one hand, this choice is quite risky, making pesantren lag behind modernity. However, the positive side is that the authenticity of pesantren values can be relatively maintained. This strategy contributed to making the santri quite safe from the invasion of new religious authority who opposed the existence of the Kiai. The phenomenon of digitizing religion may have emerged religious flexibility. The santri to some extent felt this. One of them is taking place in the easier access to classical books from various disciplines which were previously quite difficult to access due to the limited treasury of printed versions of classical books. Likewise, the students can easily get scientific insights from the Ustaz whose knowledge can be accessed from the internet media. However, this phenomenon is not enough to be able to shift the authority of the Kiai himself.

The reason is that the pesantren room as a field that forms the basis of the santri habitus has deeply internalized the culture of respect for their Kiai, not others. In addition, the limited digital space they access makes their intimacy with the religious authority of digital products relatively distant. Because of that, the Kiai's authority is irreplaceable.

\section{Conclusion}

To conclude this study of Kiai's authority, the religious authority of Kiai in Islam is maintained through the function of the pesantren as a social and cultural reproduction space. As an educational institution, pesantren reproduces its values and characteristics, including respect for the Kiai. As a social and cultural reproduction space, it becomes a field that forms habitus. Habitus is formed through the transmission of pesantren's cultural values which are naturally formed in the daily practices of the santri. 
Besides, pesantren's learning structure also emphasizes the importance of respecting Kiai. One of them is learning of Ta'lim Muta 'allim, a classic book that guides the ideal learning model in pesantren. Barakah is an important concept which further confirms the authority of Kiai. It is not only pursued by the students at the pesantren but continues until they graduated. The way to get it is by respecting Kiai. Meanwhile, the style of pesantren which remains distant from technology is also a force that maintains the authority of the Kiai in the pesantren. The digitalization of religion with the authority that occurred might oppose the existence of the Kiai as a religious authority. However, because of the limited access to technology in the pesantren and the strength which creates a climate of high respect for Kiai, so it is not enough to shift the authority of the Kiai. It is especially around the santri community who have never known the time limit for learning (nyantri) to Kiai.

\section{References}

Abaza M (2002) Debates on Islam and Knowledge in Malaysia and Egypt: Shifting Worlds. London: Routledge.

Albright J, Hartman D, \& Widin J (2018) Bourdieu's Field Theory and the Social Sciences. Singapore: Springer.

Al-Zarnuji B (1986) Ta'lim Muta'alim. Cairo: Maktabah Nahdah.

Athyal JM (2015) Religion in Southeast Asia: An Encyclopedia of Faiths and Cultures. Oxford: ABCCLIO.

Bano M (2018) Modern Islamic Authority and Social Change. Edinburg: Edinburg University Press.

Bourdieu P (1973) Cultural Reproduction and Social Reproduction in Brown R (ed). Knowledge, Education and Cultural Change: Papers in the Sociology of Education. London: Routledge.

Bruinessen M (1995) Tarekat and tarekat teachers in Madurese society. In: Van Dijk K (ed.). Across Madura Strait: The Dynamics of An Insular Society. Leiden: KITL Press.

Buisman JW, Derks M, \& Raedts P (2015) Episcopacy, Authority, and Gender: Aspects of Religious Leadership in Europe. Leiden: Koninklijke.

Bunt GR (2003) Islam in The Digital Age: E-jihad, Online Fatwas and Cyber Islamic Environments. London: Pluto Press.

Burhani AN (2018) Plural Islam and Contestation of Religious Authority in Indonesia. In: Saat N (ed.). Islam in Southeast Asia. Singapore: ISEAS 140-163.

Chaves M (1994) Secularization as declining religious authority. Social Forces, 72 (March):749-774.

Craib I (1992) Anthony Giddens. New York: Routledge.

Dreher J (2011) Alfred Schutz. In: Ritzer G \& Stepnisky J (ed.) The Wiley-Blackwell Companion to Major Social Theorists. New Jersey: Blackwell Publishing.

Eickelman DF \& Piscatori J (2004) Muslim Politics. Princeton: Princeton University Press.

Fox \& Dirjosanjoto (1989) The Memories of Village Santri from Jombang in East Java. In: James R \& Malley W (ed.). Observing Change in Asia. Australia: Crawford House Press.

Geertz C (1960) The Javanese kijaji: The changing role of a cultural broker. Comparative Studies in Society and History 2 (2):228-249. https://doi.org/10.1017/S0010417500000670.

Geertz C (1960) The Religion of Java. Chicago: University of Chicago Press.

Giddens A (1986) The Constitution of Society. California: University of California Press.

Giorgi A (2019) Mediatized catholicism - Minority voices and religious authority in the digital sphere. Religions 10 (463):1-21. https://doi.org/10.3390/rel10080463.

Hayden MC \& Wong CSD (1997) The international baccalaureate: International education and cultural preservation. Educational Studies 23 (3):349-361. https://doi.org/10.1080/0305569970230302.

Hjarvard S (2016) Mediatization and the changing authority of religion. Media, Culture and Society 38 (1):8-17. https://doi.org/10.1177/0163443715615412.

Huda M, Yusuf JB, Azmi K, \& Zakaria G (2016) Understanding Comprehensive Learning Requirements in the Light of Zarnuji's Ta'lim Muta'allim. London: Sage.

Jæger MM \& Breen R (2016) A dynamic model of cultural reproduction. American Journal of Sociology 121 (4):1079-1115. 
Milde E \& Aurini J (2015) Schools, cultural mobility and social reproduction: The case of progressive discipline. Canadian Journal of Sociology 40 (1):51-74.

Misra G \& Chandiramani R (2005) Sexuality, Gender and Rights: Exploring Theory and Practice in South and Southeast Asia. London: Sage.

Mouline N (2011) The Clerics of Islam: Religious Authority and Political Power in Saudi Arabia. Yale: Yale University Press.

OUP (2021) Preservation. In: Oxford (ed.). [Accessed 20 January 2021]. https://www. oxfordlearnersdictionaries.com/definition/american_english/preservation.

Peter F (2006) Individualization and religious authority in western European Islam. Islam and ChristianMuslim Relations 17 (1):105-118. https://doi.org/10.1080=09596410500400165.

Pribadi Y (2014) An Abangan -Like Group in a Santri Island: Religious Identity of the Blater. In: Platzdasch B \& Saravanamuttu J (ed.). Religious Diversity in Muslim Majority States in Southeast Asia. Singapura: ISEAS Pub.

Rahman F (2017) Internet and Kyais in Indonesia: Negotiation of authority in a mediatized environment. Heidelberg Journal of Religions on the Internet 9 (September):81-106. https://doi.org/10.11588/ rel.2015.0.26252.

Ritzer G \& Stepnisky J (2012) Contemporary Sociological Theory and Its Classical Roots: The Basics. California: Sage Publishing.

Robinson F (1993) Technology and religious change: Islam and the impact of print. Modern Asian Studies 27 (1):229-251. http://www.jstor.org/stable/312883.

Suradi AA \& Surahman B (2020) Kiai's role as ulama nad umara: Implication to pesantren education. Jurnal Masyarakat, Kebudayaan \& Politik 33 (2):202-211. http://dx.doi.org/10.20473/mkp. V33I22020.202-211.

Turmudi E (2006) Struggling for the Umma: Changing Leadership Roles of Kiai in Jombang, East Java. Jombang: ANU Press.

Turner BS (2007) Introduction: From enlightenment to electronic knowledge. Theory, Culture and Society 24 (2):117-134. https://doi.org/10.1177/0263276407075001.

Tzanakis M (2011) Bourdieu's Social Reproduction Thesis and The Role of Cultural Capital in Educational Attainment: A Critical Review of Key Empirical Studies. Educate 11 (1):76-90.

Vittoria AK (1998) Preserving selves: Identity work and dementia. Research on Aging 20 (1):91-136. https://doi.org/10.1177/0164027598201006.

Wahid A (2001) Menggerakkan Tradisi: Esai-Esai Pesantren. Yogyakarta: LKiS.

Wahid D (2012) Challenging religious authority: The emergence of salafi ustadhs in Indonesia. Journal of Indonesian Islam 6 (2):245-264. http://dx.doi.org/10.15642/JIIS.2012.6.2.245-264.

Widiyanto A (2016) Religious Authority and the Prospects for Religious Pluralism in Indonesia. Zurich: Lit Verlag.

Zhang X (2010) Preserving Cultural Identity through Education. Singapore: ISEAS.

Zhou M, Geng G \& Wu Z (2012) Digital Preservation Technology for Cultural Heritage. London: Springer.

Zulkifli (2013) The ulama in Indonesia: Between religious authority and symbolic power. Miqot 37 (1):180-197. http://dx.doi.org/10.30821/miqot.v37i1.79. 